\title{
modified Blalock-Taussig shunt 感染性閉塞症例の臨床像
}

\author{
山田 佑也, 鈴木 孝典, 伊藤 諒一, 郷 清貴, 大島 康徳, \\ 鬼頭 真知子, 森鼻 栄治, 河井 悟, 安田 和志 \\ あいち小児保健医療総合センター 小児心臓病センター 循環器科
}

\section{Clinical Features of Infective Modified Blalock-Taussig Shunt Obstruction}

\author{
Yuya Yamada, Takanori Suzuki, Ryoichi Itoh, Kiyotaka Go, Yasunori Ohshima, \\ Machiko Kito, Eiji Morihana, Satoru Kawai, and Kazushi Yasuda \\ Department of Pediatric Cardiology, Kids' Heart Center, Aichi Children's Health and Medical Center, Aichi, Japan
}

\begin{abstract}
Infective obstruction of a modified Blalock-Taussig shunt (mBTS) has remained poorly investigated. Here, we present six cases of this condition and discuss the therapeutic strategy. The underlying congenital heart diseases were tetralogy of Fallot $(n=2)$, complete atrioventricular septal defect with pulmonary atresia $(n=1)$, pulmonary atresia with an intact ventricular septum $(n=1)$, tricuspid atresia $(n=1)$, and truncus arteriosus communis persistens $(n=1)$. Only two cases had infection during the diagnosis of mBTS obstruction. The bacterial pathogens were methicillin-resistant coagulase-negative staphylococci $(n=3)$, Salmonella spp. $(n=1)$, Serratia marcescens $(\mathrm{n}=1)$, and Staphylococcus epidermidis $(\mathrm{n}=1)$. Furthermore, three cases had pseudoaneurysm at the proximal anastomotic site of the mBTS. Pulmonary blood flow supply was established by mBTS recanalization through catheterization $(n=1)$, right ventricular outflow tract reconstruction $(n=1)$, original BTS utilization $(n=2)$, and a larger-sized right ventricle-pulmonary artery conduit $(n=1)$. Only one patient with no alternative therapeutic options was applied with prosthetic materials. Foci of infection, such as artificial shunt graft and pseudoaneurysm, were completely removed, except in one patient who underwent effective catheterization. In conclusion, possible infection must be considered in patients with mBTS obstruction. Pseudoaneurysm at the proximal anastomotic site of the mBTS suggests infective obstruction. Furthermore, the therapeutic strategy includes 1) treatment for hypoxemia, 2) establishment of a new supply of pulmonary blood flow, 3) surgery without using prosthetic materials, and 4) removal of infection foci.
\end{abstract}

Keywords: Blalock-Taussig shunt, infective obstruction, pseudoaneurysm, infective endocarditis

modified Blalock-Taussig shunt（mBTS）感染性閉塞は症例報告が散見される程度で, 全体像は不明 な点が多い. 自験 6 例の経過から臨床像の把握と治療方針の検討を行った．基礎疾患は Fallot 四徵 2 例, 完全型房室中隔欠損兼肺動脈閉鎖・純型肺動脈閉鎖・三尖弁閉鎖・総動脈幹遺残各 1 例であった. mBTS 閉塞時に感染性閉塞と診断したのは 2 例のみで, 残りは閉塞判明後の精查で感染性閉塞と診断 した．起因菌はメチシリン耐性コアグラーゼ陰性ブドウ球菌 3 例, サルモネラ菌・セラチア菌・表皮 ブドウ球菌各 1 例であった. 3 例で mBTS 近位側吻合部に仮性瘤を形成した. 新規の肺血流供給源を original BTS (2 例), 心臟カテーテル治療による mBTS 再開通・右室流出路形成術・右室肺動脈導管 サイズアップ（各 1 例）により確保した。右室肺動脈導管サイズアップ以外では肺血流確保が不可能 な 1 例のみ人工物を使用した。 心臓カテーテル治療で mBTS が再開通した 1 例以外で感染巣（人工血 管グラフト, 仮性瘤）を除去した。 mBTS 感染性閉塞では, 閉塞との関連を疑う病歴の乏しい症例も あり注意を要する．MBTS 近位側吻合部の仮性瘤は感染性閉塞を示唆する．（1)低酸素血症への対応，

2020 年 7 月 2 日受付, 2020 年 10 月 6 日受理

著者連絡先：干813-0017 福岡市東区香椎照葉 5 丁目 1 番 1 号 福岡市立こども病院循環器科 山田佑也 doi: $10.9794 /$ jspccs. 37.57 
（2)新たな肺血流供給源の確立，（3）人工物を使用しない術式，（4)感染巣除去，を基本に症例ごとに治 療方針を検討する必要がある.

\section{はじめに}

modified Blalock-Taussig shunt (mBTS) 閉塞は, 時に致命的な低酸素血症を来しうる。 その稀な誘因と して感染が挙げられるが, 症例報告が散見される程度 であり ${ }^{1-7)}$ ，その臨床像全体の把握は不十分である. 治療方針に関しても定まった見解はない. mBTS 感染 性閉塞を来した自験 6 例の経過をもとに, 臨床像の把 握と治療方針の検討を行った.

\section{症例提示（Table 1)}

症例 $1:$ Fallot 四徵（Tetralogy of Fallot: TOF）, 男児. 前医で日齢 22 に胸骨正中切開で左 mBTS $(3.5 \mathrm{~mm})$ が行われ，その後当院に紹介された. 1 歳 1 か月時の 心臓カテーテル検査で左 mBTS 閉塞が判明した。肺 血流はわずかな順行性血流と体肺動脈側副血管でまか なわれていた。この時点で肺動脈径も細かったため, $\mathrm{mBTS}$ を再度行う方針とし, 1 歳 2 か月時に右側開胸
で右 mBTS（4.0 mm）を行った. 術後, 抗血栓療法 としてアスピリンを投与した，退院後まもなく胃腸炎 症状をきたし，便培養からサルモネラ菌が検出された ため内服抗菌薬を 1 週間投与した. しかしその後も 便培養からサルモネラ菌が持続検出され, 時に発熱, 消化器症状を来す状態が続き, 術後 4 か月時に血液 培養からもサルモネラ菌が検出された. 人工物留置状 態であるリスクを考慮し, 感染性心内膜炎（IE）に準 じた治療を行う方針とした。 入院の上，計 6 週間の 静注抗菌薬治療（セフォチアムを 2 週間投与したが 炎症反応低下に乏しく, セフタジジム十ゲンタマイシ ンに変更して 4 週間投与）を行い，便培養および血 液培養の陰転化を確認した。 入院中から経皮的酸素飽 和度 $\left(\mathrm{SpO}_{2}\right)$ が緩徐に低下し（入院時 $\mathrm{SpO}_{2} 70 \%$ 台 後半, 退院前 $\mathrm{SpO}_{2} 70 \%$ 台前半), 聴診や経皮的心臓 超音波検査で短絡血流の低下が疑われていた。 退院後 早期に心臓カテーテル検査を行い評価する予定として いた。 退院後 20 日（1歳 8 か月時, 右 mBTS 術後 6 か月), 突然の不機嫌, 嘔吐があり当院を受診した.

Table 1 Patient characteristics

\begin{tabular}{|c|c|c|c|c|c|c|}
\hline Case & $\begin{array}{l}\text { Underlying } \\
\text { congenital heart } \\
\text { diseases }\end{array}$ & $\begin{array}{l}\text { Age (months) } \\
\text { mBTS/shunt } \\
\text { obstruction }\end{array}$ & $\begin{array}{l}\text { Antithrombotic } \\
\text { therapy after mBTS }\end{array}$ & $\begin{array}{c}\text { Results of blood coagulation } \\
\text { tests at the time of } \\
\text { diagnosis of mBTS } \\
\text { obstruction }\end{array}$ & Signs of infection & $\begin{array}{l}\text { Bacterial } \\
\text { pathogen }\end{array}$ \\
\hline 1 & TOF & $14 / 20$ & aspirin & $\begin{array}{c}\text { PT-INR 1.26, APTT } 56.5 \mathrm{sec} \\
\text { Fibrinogen } 278 \mathrm{mg} / \mathrm{dL} \\
\text { D-dimer } 13.7 \mu \mathrm{g} / \mathrm{mL} \\
\text { FDP } 41.0 \mu \mathrm{g} / \mathrm{mL}\end{array}$ & bacteremia & Salmonella spp. \\
\hline 2 & cAVSD, PA & $1 / 2$ & aspirin + dipyridamole & $\begin{array}{c}\text { PT-INR 1.42, APTT } 42.8 \mathrm{sec} \\
\text { Fibrinogen } 251 \mathrm{mg} / \mathrm{dL} \\
\text { D-dimer } 2.8 \mu \mathrm{g} / \mathrm{mL} \\
\text { FDP } 5.1 \mu \mathrm{g} / \mathrm{mL}\end{array}$ & $\begin{array}{c}\text { bacteremia } \\
\text { pseudoaneurysm }\end{array}$ & $\begin{array}{c}\text { Serratia } \\
\text { marcescens }\end{array}$ \\
\hline 3 & PAIVS & $0 / 2$ & aspirin + dipyridamole & $\begin{array}{c}\text { PT-INR 1.10, APTT } 41.7 \mathrm{sec} \\
\text { Fibrinogen } 297 \mathrm{mg} / \mathrm{dL} \\
\text { D-dimer } 2.0 \mu \mathrm{g} / \mathrm{mL} \\
\text { FDP } 4.5 \mu \mathrm{g} / \mathrm{mL}\end{array}$ & $\begin{array}{c}\text { bacteremia } \\
\text { pseudoaneurysm }\end{array}$ & MRCNS \\
\hline 4 & TOF & $5 / 12$ & aspirin $\rightarrow$ dipyridamole & $\begin{array}{l}\text { PT-INR 1.18, APTT } 30.9 \mathrm{sec} \\
\text { Fibrinogen } 187 \mathrm{mg} / \mathrm{dL}\end{array}$ & bacteremia & $\begin{array}{l}\text { Staphylococcus } \\
\text { epidermidis }\end{array}$ \\
\hline 5 & $\mathrm{TA}(1 \mathrm{~b})$ & $1 / 4$ & aspirin & $\begin{array}{l}\text { PT-INR 1.21, APTT } 34.4 \mathrm{sec} \\
\text { Fibrinogen } 148 \mathrm{mg} / \mathrm{dL}\end{array}$ & bacteremia & MRCNS \\
\hline 6 & TAC & $7 / 10$ & aspirin & $\begin{array}{c}\text { PT-INR 1.10, APTT } 34.4 \mathrm{sec} \\
\text { Fibrinogen } 188 \mathrm{mg} / \mathrm{dL} \\
\text { D-dimer } 1.9 \mu \mathrm{g} / \mathrm{mL} \\
\text { FDP } 3.9 \mu \mathrm{g} / \mathrm{mL}\end{array}$ & $\begin{array}{c}\text { bacteremia } \\
\text { pseudoaneurysm }\end{array}$ & MRCNS \\
\hline
\end{tabular}

cAVSD, complete atrioventricular septal defect; mBTS, modified Blalock-Taussig shunt; MRCNS, methicillin-resistant coagulase-negative staphylococci; PA, pulmonary atresia; PAIVS, pulmonary atresia with intact ventricular septum; TA, tricuspid atresia; TAC, truncus arteriosus communis; TOF, tetralogy of Fallot 

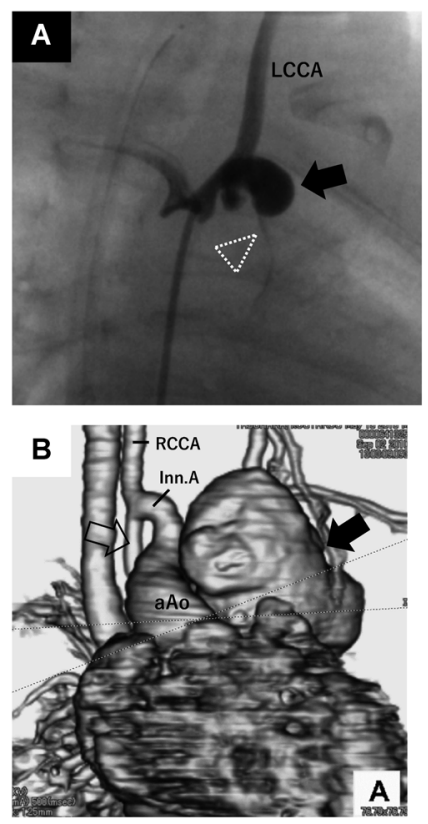
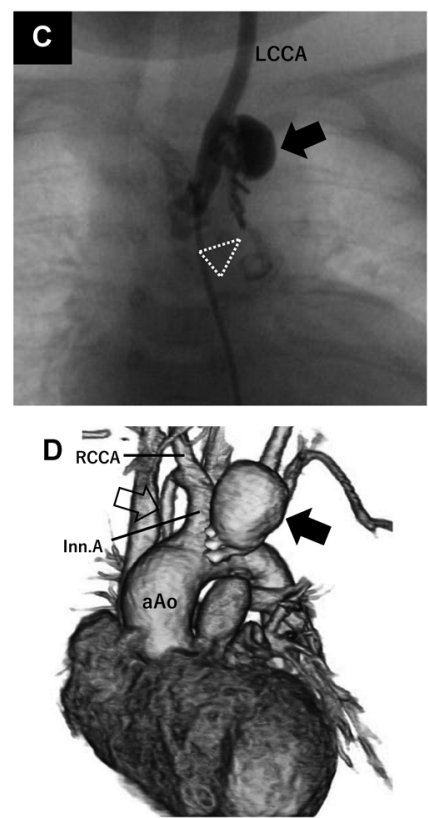

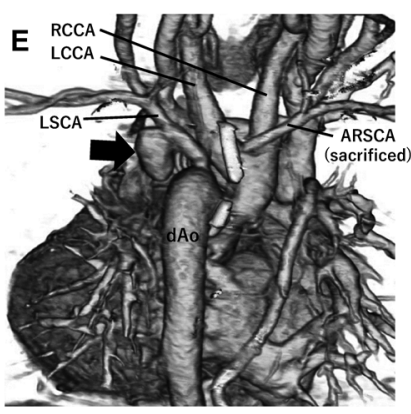

Fig. 1 Angiographic and three-dimensional computed tomographic images of pseudoaneurysm

A) Angiographic image in case 2. Modified Blalock-Taussig shunt (mBTS) was almost completely obstructed (dotted arrowhead) and pseudoaneurysm (solid arrow) was formed at the proximal anastomotic site of the mBTS. B) Three-dimensional computed tomographic (3DCT) image 23 days after angiography in case 2. Pseudoaneurysm was markedly expanded (solid arrow). Right original BTS was represented (open arrow). C) Angiographic image in in case 3. Note almost completely obstructive mBTS (dotted arrowhead) and pseudoaneurysm (solid arrow) at the proximal anastomotic site of the mBTS, similar to case 2. D) 3DCT image 8 days after angiography in case 3. Note expanded pseudoaneurysm (solid arrow) and right original BTS (open arrow), also similar to case 2. E) 3DCT image in case 6. Pseudoaneurysm (solid arrow) was formed at the proximal anastomotic site of the mBTS. aAo, ascending aorta; ARSCA, aberrant right subclavian artery; dAo, descending aorta; Inn. A, innominate artery; LCCA, left common carotid artery; LSCA, left subclavian artery; RCCA, right common carotid artery

$\mathrm{SpO}_{2} 20 \%$ 未満で, 経皮的心臟超音波検査で短絡血流 を確認できなかった。 すみやかに人工呼吸器管理を開 始し, $\mathrm{SpO}_{2} 50 \%$ 台に上昇した. 心臓カテーテル検査 で右 mBTS の完全閉塞を確認し, mBTS 感染性閉塞 と診断した。 まずは心臓カテーテル治療で再開通を図 る方針とし, バルーン拡張術, ウロキナーゼ局所投与 で開通を試みたが再開通は得られなかった。低酸素血 症が持続したため同日体外膜型人工肺（ECMO）を 装着し, 翌日に右室流出路形成術, 人工血管グラフト 除去を行った. 右室流出路形成は漏斗部心筋切除のみ で，人工物は使用しなかった。除去した人工血管グラ フトの培養からサルモネラ菌が検出された. 計 4 週間 の抗菌薬治療（セフタジジム 4 週間十ゲンタマイシン 4 週間) を行った。 1 歳 11 か月時に心内修復術を行っ た.

症例 2 : 完全型房室中隔欠損兼肺動脈閉鎖, 男児. 前 医で上記心疾患と食道閉鎖症を診断され, 日齢 2 に当 院に搬送された。搬送同日に気管食道瘻離断, 胃瘦造 設術を行った。食道閉鎖症はいわゆる long-gap であ
り，一期的な吻合が不可能であった。 月齢 1 に胸骨 正中切開で左 mBTS $(3.5 \mathrm{~mm})$ を行った. 術後, 抗 血栓療法としてアスピリンとジピリダモールを投与し た. 左 mBTS 術後 25 日に曼下機能温存と食道延長術 のために頸部食道瘦を増設した。. 左 mBTS 術後 34 日 に発熱し, 血液培養からセラチア菌が検出された。抗 菌薬治療を開始したが, 発熱 3 日後から低酸素血症が 徐々に進行したため（それまでは $\mathrm{SpO}_{2} 80 \%$ 台であっ たが, 安静時 $\mathrm{SpO}_{2} 60-70 \%$ 台, 啼泣時 $\mathrm{SpO}_{2} 30 \%$ 台), 人工呼吸器管理を開始した。同日施行した心臓力テー テル検査（月齢 2）で左 mBTS 閉塞と左 mBTS 近位 側吻合部の仮性瘤が確認され（Fig. 1A), mBTS 感染 性閉塞と診断した。体肺動脈側副血管を認め, 最低 限の酸素化維持に寄与していると考えられた。治療 方針の選択にあたり,（1）肺血流維持, (2)人工物使 用を避けること，を旨に検討し，右 original BTS を 先行, 酸素化の担保された状態で人工血管グラフト 除去，仮性瘤切除を行う方針とした．両方向性 Glenn 手術（BDG）も検討したが，肺血管床が不十分であ 
り, original BTS を選択した. 敗血症およびそれに伴 う播種性血管内凝固症候群の治療を行い, 全身状態が 安定した後に右側開胸で, 直接右房アプローチによる veno-venous ECMO 下に酸素化を維持した状態で右 original BTS を行った. 術中, 肺動脈切開時に白褐色 の液体が流失し, 培養からセラチア菌が検出された。 その後仮性瘤は増大したが (Fig. 1B), 破裂は免れ経 過観察可能であった. original BTS の 10 日後に胸骨 正中切開で人工血管グラフト除去, 仮性瘤切除を行っ た. 計 8 週間の抗菌薬治療（肝機能障害等の副作用を 生じたためセフタジジム, バンコマイシン, アミカシ ン, パニペネム/ベタミプロン, ホスホマイシン, メ ロペネム, フロモキセフを順次変更しながら併用, 計 8 週間）を行った. 本児はこの一連の治療を経て左肺 動脈完全閉塞状態となった. 次なる治療として右片肺 Fontan 手術もしくは Rastelli 手術を検討したが, 肺 の条件が不良であること, 元の感染巣に人工血管を用 いる手術であることを考慮し，いずれも困難と判断し た. また食道閉鎖症根治術のためには右肺の圧排が必 要であるが, 右肺に大きく依存した血行動態下での長 時間手術は不可能と判断した. 3 歳 6 か月まで同様の 状態で経過観察し, 転居に伴い当院での治療を終了し た.

症例 3 : 純型肺動脈閉鎖, 女览. 日齢 11 に行った 心蔵カテーテル検査結果から単心室修復の方針とし た. 日齢 17 に胸骨正中切開で Brock 手術, 左 mBTS （3.5 mm）を行った. 術後, 抗血栓療法としてアスピ リンとジピリダモールを投与した。 退院時には $\mathrm{SpO}_{2}$ $80 \%$ 台中盤であった. 外来経過観察中, 創部の残糸 および周囲の発赤があり，皮膚表層創部感染と判断し たが, 経過観察のみで改善した. 徐々に低酸素血症 が進行したため ( $\mathrm{SpO}_{2} 70 \%$ 前後), BTS 狭窄を疑い 月齢 2 に行った心蔵カテーテル検査で左 mBTS 閉塞 と左 mBTS 近位側吻合部の仮性瘤が確認された（Fig. 1C). 平均右肺静脈楔入圧 $10 \mathrm{mmHg}$, 肺血管抵抗 $=$ 2.93 Wood unit $\mathrm{m}^{2}$, PA index $237 \mathrm{~mm} / \mathrm{m}^{2}$ であった. 心臓カテーテル検査時に提出した血液培養からメチシ リン耐性コアグラーゼ陰性ブドウ球菌 (methicillin-resistant coagulase-negative staphylococci: MRCNS）が 検出され, mBTS 感染性閉塞と診断した. 症例 2 と 同様の治療戦略とし, 先行して右側開胸で右 original BTS を行った. その後仮性瘤は増大傾向であったが 破裂は免れ（Fig. 1D), original BTSの 7 日後に人工 血管グラフト除去, 仮性瘤切除を行った. 提出した組 織の培養からも MRCNS が検出された. 計 6 週間の 抗菌薬治療（バンコマイシン, テイコプラニン, リネ
ゾリドを副作用のため順に変更して計 6 週間）を行っ た. 月齢 8 にBDGを, 1 歳 8 か月時に Fontan 手術 を行った.

症例 $4:$ TOF, 男児. 月齢 5 に胸骨正中切開で右 mBTS $(4.0 \mathrm{~mm})$ を行った. 術後, 抗血栓療法として アスピリンを投与したが，肝機能障害のためジピリダ モールに変更して投与継続した．その後低酸素血症の 進行はなく推移した。一度胃腸炎症状を呈した以外に は感染症罹患はなかった。 心内修復術を見据えて 1 歳 0 か月時に行った心蔵カテーテル検査で右 mBTS の完 全閉塞が判明した。仮性瘤は認めなかった。順行性血 流のみで肺血流はまかなえていると判断し, transannular patchを用いた心内修復術を行う方針とした. 1 歳 3 か月時に予定手術を行ったが，人工血管グラフト を結紮した際に白褐色の液体が流出し, 迅速検査でグ ラム陽性球菌が検出され, mBTS 感染性閉塞と診断し た（のちに培養から表皮ブドウ球菌が検出された）. この状況で人工物を用いた手術は望ましくないと判断 し, 人工血管グラフト除去のみで手術終了した. 計 4 週間の抗菌薬治療（セファゾリン 4 週間十ゲンタマイ シン 1 週間) を行った. 以後感染は問題とならず, 酸 素化も経過観察可能な範囲であった. 1 歳 6 か月で心 内修復術を行った。

症例 5 : 三尖弁閉鎖 (Ib 型), 男児. 月齢 1 に胸骨 正中切開で右 $\mathrm{mBTS}(3.5 \mathrm{~mm})$ を行った. 術後, 抗 血栓療法としてアスピリンを投与した. 術後, $\mathrm{SpO}_{2}$ $70 \%$ 台と酸素吸入下でも低酸素血症の状態であり, また両側肺動脈径が細かったため, mBTS を追加して 将来の Fontan 循環に向けて肺血管床拡大を図る方針 とした。 月齢 3 に胸骨正中切開で左 $\mathrm{mBTS}(3.5 \mathrm{~mm})$ を追加した. 術後, 酸素使用下で $\mathrm{SpO}_{2} 80 \%$ 前後で あった．経過中に発熱等の感染を示唆する症状はな かった。 術後 24 日目（月齢 4) の造影 CT 検査で右 mBTS 閉塞が判明した。仮性瘤は認めなかった。 1) BDG，2）BTS 再開通もしくは再建，を選択肢に挙げ て治療方針を検討した。この時点でもなお両側肺動脈 径が細く, 肺血管床成長を待ってから BDGに進むこ とが望ましいと判断し, 後者を選択した. 侵襲度を考 慮して心臓カテーテル治療による右 mBTS 再開通を 図る方針とした。右 mBTS は完全閉塞していたが, バルーン拡張術により再開通が得られた。 心臓カテー テル治療中, バルーン拡張術に先立ち mBTS 近傍で 採血した血液培養から MRCNS が検出されたことが 心臓力テーテル治療翌日に判明した. mBTS 感染性閉 塞と診断し, 計 6 週間の抗菌薬治療（バンコマイシ ン 6 週間+リファンピシン 6 週間十ゲンタマイシン 2 
週間）を行った。血液培養からは心臓カテーテル治療 2 日後まで持続して MRCNS が検出され, 以後陰転化 した. 月齢 10 にBDGを行ったが, 右 $\mathrm{mBTS}$ はその 時点まで問題なく開存が得られていた. 現在 Fontan 手術待機中である.

症例 6 : 総動脈幹遺残, 大動脈弓離断, 右鎖骨下動脈 起始異常 (aberrant right subclavian artery: ARSCA), 男児.

日齢 10 に両側肺動脈絞扼術, 月齢 3 に大動脈弓修 復術と姑息的右室流出路形成術 (ringed PTFE $6 \mathrm{~mm}$ ) をいずれも胸骨正中切開で行った. 術後, 抗血栓療法 としてアスピリンを投与した. その後左肺動脈狭窄 が指摘され, 肺動脈成長を促すために左側開胸で左 mBTS（3.5 mm）を月齢 7 に行い, 術後もアスピリン 投与を継続した。 退院時 $\mathrm{SpO}_{2}$ は $80 \%$ 台中盤であっ た. 退院後, 気道感染により 3 日間発熱したが, それ 以外に感染症状はなかった. 月齢 10 の定期外来受診 時に $\mathrm{SpO}_{2} 60 \%$ 台の低酸素血症を認めた. 造影 $\mathrm{CT}$ 検 查で左 mBTS 閉塞と左 mBTS 近位側吻合部の仮性瘤 が判明した（Fig. 1E).また血液培養から MRCNS が 検出され, mBTS 感染性閉塞と診断した. 症例 $2 \cdot 3$ で行った original BTS による治療戦略は ARSCA が過 去の手術で既に離断されており不可能であるため, 右 室肺動脈導管のサイズアップを行う方針とした. 人工 物使用となるが, 代替手段がなくやむを得ないと判断 した. 鎮静下に高流量鼻カニュラ酸素療法を行い待機
し，準緊急で右室肺動脈導管のサイズアップ (ringed PTFE $7 \mathrm{~mm}$ ), 人工血管グラフト除去, 仮性瘤切除を 行った. 計 6 週間の抗菌薬治療（バンコマイシン 6 週 間十リファンピシン 6 週間) を行った. 現在外来経過 観察中である.

\section{倫理的配慮}

この研究と論文発表について, 当院倫理審査委員会 の承認を受けている（承認番号 2020015）.

\section{考察}

mBTS 感染性閉塞を来した自験 6 例の経過をもと に，その臨床像と治療方針に関して考察を行った。

mBTS 閉塞判明時点で感染が関与していると判断し たのは, 閉塞前にそれぞれサルモネラ菌・セラチア菌 の菌血症に罹患していた症例 1,2 の 2 例のみであっ た. 残りの症例では閉塞判明後の精査で感染性閉塞が 判明した. 症例 3, 5, 6 では mBTS 閉塞判明後に提出 した血液培養の結果で, 症例 4 では術中所見で初めて 感染の関与を認識した。症例 3 では皮膚表層創部感 染, 症例 4 では胃腸炎, 症例 6 では気道感染が経過中 にあったが，いずれも症状としては軽微であった。こ れらの症例では, mBTS 閉塞に対する感染の関与を閉 塞判明時点で想定することが困難である. 症例 3, 5, 6 では症例 1,2 の経験を元に mBTS 閉塞判明直後に血

Table 2 Treatment

\begin{tabular}{|c|c|c|c|c|c|c|}
\hline Case & $\begin{array}{l}\text { Underlying } \\
\text { congenital heart } \\
\text { diseases }\end{array}$ & Antibiotic therapy (duration) & $\begin{array}{l}\text { Removal of focus } \\
\text { of infection }\end{array}$ & $\begin{array}{l}\text { Newly added source } \\
\text { of pulmonary flow }\end{array}$ & $\begin{array}{c}\text { Staged } \\
\text { operation }\end{array}$ & $\begin{array}{l}\text { Use of } \\
\text { prosthetic } \\
\text { material }\end{array}$ \\
\hline 1 & TOF & $\begin{array}{c}\text { CTM (2wks), CAZ+GM (4wks) } \\
\text { CAZ+GM (4wks) }\end{array}$ & shunt graft & $\begin{array}{l}\text { RVOTR (myocardial } \\
\text { resection) }\end{array}$ & - & - \\
\hline 2 & cAVSD, PA & $\begin{array}{c}\text { CAZ, VCM, AMK, PAPM/BP } \\
\text { FOM, MEPM, FMOX (total } \\
8 \text { wks) }\end{array}$ & $\begin{array}{c}\text { shunt graft } \\
\text { pseudoaneurysm }\end{array}$ & original BTS & + & - \\
\hline 3 & PAIVS & VCM, TEIC, LZD (total 6 wks) & $\begin{array}{c}\text { shunt graft } \\
\text { pseudoaneurysm }\end{array}$ & original BTS & + & - \\
\hline 4 & TOF & CEZ (4wks) + GM (1 wk) & shunt graft & - & - & - \\
\hline 5 & $\mathrm{TA}(1 \mathrm{~b})$ & $\mathrm{VCM}+\mathrm{RFP}(6 \mathrm{wks})+\mathrm{GM}(2 \mathrm{wks})$ & - & $\begin{array}{l}\text { cathter intervention: } \\
\text { recanalization of } \\
\text { mBTS }\end{array}$ & - & - \\
\hline 6 & TAC & $\mathrm{VCM}+\mathrm{RFP}(6 \mathrm{wks})$ & $\begin{array}{c}\text { shunt graft } \\
\text { pseudoaneurysm }\end{array}$ & $\begin{array}{c}\text { Larger-sized RV-PA } \\
\text { conduit }\end{array}$ & - & + \\
\hline
\end{tabular}

AMK, amikacin; cAVSD, complete atrioventricular septal defect; CAZ, ceftazidime; CEZ, cefazolin; CTM, cefotiam; FMOX, flomoxef; FOM, fosfomycin; GM, gentamicin; LZD, linezolid; mBTS, modified Blalock-Taussig shunt; MEPM, meropenem; MRCNS, methicillin-resistant coagulase-negative staphylococci; PA, pulmonary atresia; PAIVS, pulmonary atresia with intact ventricular septum; PAPM/BP, panipenem/betamipron; RFP, rifampicin; RVOTR, right ventricular outflow tract reconstruction; RV-PA, right ventricle-pulmonary artery; TA, tricuspid atresia; TAC, truncus arteriosus communis; TEIC, teicoplanin; TOF, tetralogy of Fallot; VCM, vancomycin 
液培養検査を提出し, mBTS 感染性閉塞の診断に至つ たが, 症例 4 では心内修復術時の術中所見で初めて mBTS 感染性閉塞の診断に至り, 術式変更を余儀なく された. mBTS 感染性閉塞例では, 閉塞判明前に閉塞 との関連を疑う病歴の乏しい症例もある。一般的に, mBTS 閉塞の原因として常に感染を念頭に置く必要が ある. また, 逆に感染を起こした児が低酸素血症など の mBTS 閉塞を疑う臨床所見を示した場合には, 早 期に造影 CT や心臓カテーテル検査などの画像評価を 行い, mBTS の開存に関する評価を行う必要がある.

症例 1 でサルモネラ菌血症入院中に低酸素血症を認 め, mBTS 狭窄を疑っていたものの画像評価が遅れた ために, 結果として ECMO を導入せざるを得ない状 況を招いたことは反省すべき点であった.

症例 2, 3, 6 で mBTS 近位側吻合部の仮性瘤を認め た (Fig. 1). 感染性 mBTS 閉塞に伴う mBTS 近位 側吻合部の感染性仮性瘤はこれまでも報告されてお $り^{1-7)}$, 感染の関与を示唆する重要な所見となる.

mBTS 感染性閉塞に対する治療方針の要点は, (1) 低酸素血症への対応，(2)新たな肺血流供給源の確 立, (3) 人工物を使用しない術式, (4) 感染巣除去,

である（Table 2).（1）低酸素血症への対応に関して は, 自験例では 1 例で ECMO 装着を要し， 2 例で人 工呼吸器管理を行った. 高流量鼻力ニュラ酸素療法と 経鼻酸素投与を行ったのが各 1 例, 介入なく経過観察 したのが 1 例であった. 低酸素血症の程度に応じて, 適切な介入を行う必要がある。（2）(3)新たな肺血流 供給源を, 人工物を使用しない術式で確立する必要が ある. 症例 1 では漏斗部心筋切除のみの右室流出路形 成により, 症例 2, 3 では original BTS により人工物 は使用せず肺血流を確保した。症例 4, 5 では mBTS 閉塞時点で感染性閉塞と診断していなかったが, 症例 4 では肺動脈順行性血流のみで, 症例 5 では心蔵力 テーテル治療による mBTS 再開通により肺血流供給 源を確保したため, 新規の人工物は使用しなかった. 症例 6 では ARSCA が過去の手術で既に離断されてお り original BTS が不可能であるため, 右室肺動脈導管 のサイズアップを行う方針とした. 代替手段がないた め, 本症例ではやむを得ず人工物を使用した. (4)症 例 5 を除き, 感染巣除去 (人工血管グラフト除去, 仮 性瘤切除）を行った。症例 5 では, mBTS 閉塞が判明 した際に感染性閉塞の可能性を疑っておらず，心蔵力 テーテル治療を行いmBTSが再開通した。 心臓カテー テル治療時に提出した血液培養検査で初めて mBTS 感染性閉塞の診断がついたため, その後結局人工血管 グラフト除去はせずに抗菌薬治療を行った. 感染巣除
去は治療の肝であり, mBTS 閉塞が判明した際には, 感染性閉塞を念頭に置く必要がある.

治療方針に関しては，上記(1)〜（4)を基本とし， 個々の症例で最適な手段を検討する必要がある. 感 染性 mBTS 閉塞に対する肺血流維持の方法として $\mathrm{mBTS}$ 再建 ${ }^{1,4)}$, BDG 施行 ${ }^{3,5)}$ などの報告がある.

Carvalho らは感染性 mBTS 閉塞後, 別部位に mBTS 再建を行ったものの再度感染性閉塞を起こし死亡し た症例を報告し，人工物を用いた手術後には反復感 染の危険性が高くなることに警鐘を鳴らしている ${ }^{4)}$.

当院から, 症例 2,3 で行った側開胸による original BTS を使用した段階手術による治療戦略を報告して いる ${ }^{8)}$. 閉塞した BTS と対側の側開胸手術による original BTSにより術野污染を避け, かつ人工物を使 用せずに肺血流を確保する手段として有用であると考 えられる．ただし待機期間に仮性瘤破裂のリスクを伴 うため, 仮性瘤のサイズの評価を密に行うことと, 状 況が許す限り段階手術の間隔を短くすることが必要で ある．また仮性瘤形成下での側開胸手術は術中瘤破裂 への対応が困難となるため, その点も加味して適応を 十分に検討する必要がある。

\section{利益相反}

本論文について，開示すべき利益相反（COI）はない.

\section{著者の役割}

山田佑也は筆頭著者として論文作成を行った．鈴木孝典，伊藤 諒一, 郷清貴, 大島康徳, 鬼頭真知子, 森鼻栄治, 河井悟は論 文の重要な知的内容に関わる批判的校閲に関与した. 安田和志 は論文内容に関する直接的指導を行った.

\section{引用文献}

1) Coren ME, Green C, Yates R, et al: Complications of modified Blalock-Taussig shunts mimicking pulmonary disease. Arch Dis Child 1998; 79: 361-362

2) Matsuhisa $H$, Yoshimura $N$, Kitahara J, et al: An infected pseudoaneurysm following a modified Blalock-Taussig shunt. Interact Cardiovasc Thorac Surg 2009; 8: 108-110

3) Dimas VV, Kovalchin JP, McKenzie ED, et al: Infected pseudoaneurysm of a right modified Blalock-Taussig shunt. Pediatr Cardiol 2004; 25: 700-701

4) Carvalho JS, Belcher P, Knight WB: Infection of modified Blalock shunts. Br Heart J 1987; 58: 287-290

5) Sasaki Y, Ozawa T, Katayanagi T, et al: Bidirectional Glenn procedure for an infected modified Blalock-Taussig shunt. Gen Thorac Cardiovasc Surg 2012; 60: 355-358

6) Sundararaghavan S, Khalid O, Suarez WA, et al: Single-stage repair of tetralogy of Fallot with pseudoaneurysm: A unique approach. Ann Thorac Surg 2004; 77: 
2183-2184

7) Parvathy U, Balakrishnan KR, Ranjith MS, et al: False aneurysm following modified Blalock-Taussig shunt. Pediatr Cardiol 2002; 23: 178-181

8) Okada N, Murayama H, Hasegawa H: Optimal surgical management using a classic Blalock-Taussig shunt for an infected pseudoaneurysm after a modified BlalockTaussig shunt procedure. Ann Thorac Surg 2016; 101: 1992-1995 